DOI: 10.20472/IAC.2019.048.004

\author{
PRIYA BAGUANT \\ Higher Colleges of Technology, United Arab Emirates \\ ROBERTA FENECH \\ Higher Colleges of Technology, United Arab Emirates
}

\title{
WORK READINESS OF YOUNG GRADUATES ACROSS DIFFERENT MAJOR SPECIALISATIONS :CASE OF UNITED ARAB EMIRATES
}

\begin{abstract}
:
The employability of locals in the United Arab Emirates is a national priority and an integral part of Emiratisation which is an affirmative action policy of the United Arab Emirates Government that promotes preferential hiring status to Emiratis to safeguard national identity, economic sustainability, and political stability (Modarress, Ansari and Lockwood, 2013). The purpose of this research is to study the work readiness of Emirati graduating students across various specializations. The theoretical framework for this study is the four-factor model by Caballero, Walker and Fuller-Tyszkiewicz (2011). The four factors are personal work characteristics, organizational acumen, work competence and social intelligence. The research conducted so far on work readiness of graduates has been limited to particular disciplines (Walker, Storey, Costa, Leung, 2015; Dermott, 2007; Jollands, Jolly and Molyneaux, 2012; Haigh, Ell and Mackisack, 2013; Dermott and Ortiz, 2017). This study contributes to the existing body of knowledge as it does not focus on a single specialization and takes a broad exploratory look at work readiness across five specializations, namely business, information technology, health sciences, applied communication and engineering. 302 graduating Emirati students chosen randomly from various disciplines in different institutions participated in this quantitative research study by filling in a 60 -item work readiness questionnaire. The main findings of this study is that specializations in tertiary education vary not only in terms of curriculum, technical knowledge, skills and abilities taught, but also in the preparation for employment which influences the perceptions of graduating students of their work readiness; graduating students in a health specialization perceiving to be the most work ready and graduating students in a business specialization perceiving to be the least work ready.
\end{abstract}

\section{Keywords:}

Work readiness; tertiary education; Emiratization; Work readiness scale. 